\title{
SOSIALISASI PENGELOLAAN LIMBAH RUMAH TANGGA SECARA MANDIRI UNTUK EFEKTIFITAS PENGOLAHANNYA
}

\author{
Ni'matur Rohmah'), Yuni Susanti1), Yeni Variyana1), Lukman Haris Kurniawan'), \\ Muslimin Nasution"), Arga Bayramadhan'1) \\ 1)Program Studi Teknik kimia, Institut Teknologi dan Bisnis Muhammadiyah, Banyuwangi, Jawa Timur, Indonesia
}

Corresponding author : Ni'matur Rohmah

E-mail : nikmaturrohmah@itbmb.ac.id

Diterima 08 Juli 2021, Direvisi 19 Juli 2021, Disetujui 19 Juli 2021

\begin{abstract}
ABSTRAK
Limbah bersumber dari berbagai aktivitas manusia diantaranya aktivitas rumah tangga, industri, perdagangan, pertanian, perkantoran, dan sisa pembangunan. Namun aktivitas yang paling banyak menyumbang limbah adalah aktivitas rumah tangga. Pengelolaan limbah rumah tangga di desa masih dilakukan secara tradisional yaitu melalui penimbunan pada lahan kosong. Umumnya masyarakat desa menggunakan cara pembakaran untuk mengatasi penumpukan limbah tersebut. Kegiatan pengabdian masyarakat ini bertujuan untuk menambah pengetahuan dan menumbuhkan kesadaran masyarakat untuk menjaga kelestarian lingkungan melalui pengelolaan limbah rumah tangga secara mandiri. Penyuluhan pengelolaan limbah rumah tangga di desa Kaliploso melibatkan 30 peserta. Penyajian materi diawali dengan memberikan stimulus terkait pengetahuan peserta terhadap limbah rumah tangga dan jenis-jenisnya, kemudian dilanjutkan penyajian materi dengan metode ceramah. Diskusi yang dilakukan setelah penyajian materi diikuti peserta dengan antusias dan menghasilkan ide baru tentang pengelolaan limbah rumah tangga secara mandiri. Hasil kegiatan ini meningkatkan pengetahuan masyarakat dengan tingkat pemahaman 100\% (30 peserta) dan menumbuhkan kesadaran masyarakat yang dibuktikan dengan munculnya ide percontohan pelaksana pengelolaan limbah rumah tangga jenis anorganik sebanyak $43,33 \%$ (13 peserta).
\end{abstract}

Kata kunci: pengelolaan; limbah rumah tangga; desa Kaliploso

\begin{abstract}
Waste comes from human activities such as household activities, industries, commerce, agriculture, offices, and residual of construction. But the most contributing waste is household activities. Management of household solid waste in the village is using traditional methods, by piling up on vacant land. The villagers are burning to overcome the pile. This activity aims to increase knowledge and public awareness to protect the environment through household waste management independently. Education of household waste management in Kaliploso village involves 30 participants. Presentation began by providing stimulus related to participants knowledge of definition and types of household waste, then continued with educate about household waste. The discussion was attended by participants enthusiastically and it produced new ideas about self-management of household waste. The results of this activity increase public knowledge with an understanding level of 100\% (30 participants) and raise public awareness as evidenced by the emergence of pilot ideas for implementing inorganic types of household waste management as much as $43.33 \%$ (13 participants).
\end{abstract}

Keywords: management; household waste, Kaliploso village

\section{PENDAHULUAN}

Kelestarian lingkungan merupakan dambaan bagi masyarakat kini dan nanti. Kelestarian lingkungan dapat diraih jika masyarakatnya bertanggungjawab atas kebersihan dan keindahan lingkungan sekitarnya. Namun banyak hal yang menghalangi usaha pelestarian lingkungan, salah satunya adalah limbah/ sampah. Sampah adalah sisa kegiatan sehari-hari manusia dan atau proses alam yang berbentuk padat.
Sampah bersumber dari berbagai aktivitas manusia antara lain aktivitas rumah tangga, industri, perdagangan, pertanian, perkantoran, dan sisa pembangunan. Namun aktivitas yang paling banyak menyumbang sampah adalah aktivitas rumah tangga (Suwerda, 2012). Aktivitas rumah tangga menghasilkan berbagai jenis macam limbah yang cukup lengkap diantaranya bersifat kering, basah, dan cair.

Semakin tinggi aktivitas manusia maka berbanding lurus dengan banyaknya sampah 
yang dihasilkan. Maka sebagai upaya untuk mencegah pencemaran lingkungan yang dihasilkan oleh sampah, maka pengolahan sampah di lingkup rumah tangga perlu diprioritaskan. Pengelolaan sampah adalah semua kegiatan yang dilakukan untuk menangani sampah sejak ditimbulkan sampai dengan pembuangan akhir (Sejati, 2009).

Limbah rumah tangga menyumbang tiga jenis sesuai dengan penggolongan sampah menurut Sejati (2009) yang digolongkan berdasarkan sifatnya, yaitu sampah organik, sampah anorganik, dan sampah berbahaya. Sampah organik adalah sampah yang mudah membusuk seperti sisa makanan, sayuran, daun-daun kering, dan sebagainya. Sedangkan sampah anorganik, yaitu sampah yang tidak mudah membusuk, seperti plastik wadah pembungkus makanan, kertas, botol dan gelas minuman, kaleng, kayu, dan sebagainya. Dan sampah berbahaya diantaranya baterai, jarum suntik, pecahan kaca, dan limbah racun kimia. Berbagai jenis sampah organik dan anorganik yang dihasilkan dari limbah rumah tangga secara keseluruhan hanya ditimbun begitu saja.

Pengelolaan limbah rumah tangga di desa masih dilakukan secara tradisional yaitu melalui penimbunan pada lahan kosong karena tidak tersedianya TPA (Tempat pembuangan Akhir). Masyarakat desa cenderung melakukan pembakaran untuk mengatasi penumpukan limbah rumah tangga. Proses pembakaran ini memiliki kelemahan yaitu tidak semua sampah dapat terbakar dengan baik dan juga menimbulkan masalah baru yakni polusi udara (Nugroho, 2013). Oleh karena itu pembakaran merupakan pilihan proses pengolahan sampah yang kurang efektif untuk mengatasi hal tersebut.

Berdasarkan permasalahan yang ada, maka melalui program pengabdian kepada masyarakat ini diharapkan mampu menambah pengetahuan masyarakat mengenai pentingnya mengelola sampah di lingkup rumah tangga dan menjaga kebersihan lingkungan secara bijak.

\section{METODE}

Kegiatan penyuluhan ini dilaksanakan di Desa Kaliploso, Kecamatan Cluring, Kabupaten Banyuwangi dengan beberapa tahapan kegiatan sebagai berikut:

\section{Survey lapangan}

Survey lapangan dilakukan secara menyeluruh di Desa Kaliploso dengan tujuan mengamati situasi dan kondisi lingkungan dan kebiasaan masyarakat sebagai objek kegiatan. 2. Koordinasi dengan pihak yang bersangkutan

Tujuan koordinasi yaitu untuk menentukan kesepakatan waktu, tempat, dan sasaran masyarakat yang akan digunakan untuk kegiatan pengabdian masyarakat ini.

3. Tahap persiapan

Persiapan dilakukan oleh seluruh Tim pengabdian kepada masyarakat Program studi Teknik Kimia ITBM Banyuwangi dengan mempersiapkan materi dan alat yang digunakan untuk mendukung pelaksanaan pengabdian.

4. Pelaksanaan penyuluhan

Pelaksanaan penyuluhan dilakukan dengan mengumpulkan warga dengan mematuhi protokol kesehatan yang baik di balai desa Kaliploso dengan metode sebagai berikut: 1) Ceramah; Metode ini menjelaskan materi tentang limbah padat atau sampah meliputi a. Pengubahan paradigma masyarakat tentang sampah; b. Pemberian pemahaman tentang jenis-jenis, bahaya sampah dan akibat yang ditimbulkannya; c. Edukasi tentang tindakan yang benar dalam menangani limbah rumah tangga, yaitu dengan melakukan pemilahan limbah organik dan anorganik; dan d. Edukasi mengenai konsep PS3R (Pengelolaan Sampah Reduce, Reuse, Recycle). 2) Diskusi; Tim dan peserta penyuluhan berdiskusi terkait materi yang telah diberikan mengenai hal-hal yang belum mereka pahami dan ide-ide kegiatan pengelolaan serta pengolahan limbah rumah tangga yang baik.

5. Evaluasi program

Kegiatan evaluasi dilakukan untuk menilai keseluruhan kegiatan dan capaian peserta penyuluhan sebelum dan sesudah kegiatan. Evaluasi dilakukan dengan menanyakan kembali terkait materi yang telah diberikan.

\section{HASIL DAN PEMBAHASAN}

Tahapan kegiatan yang pertama adalah survey. Berdasarkan hasil survey diketahui bahwa masyarakat desa mengatasi sampah dengan menimbun di lahan kosong dan membakarnya. Secara geografis desa Kaliploso memiliki banyak sungai, hal ini berpotensi menimbulkan kebiasaan warga membuang limbah rumah tangga ke sungai.

Tahap koordinasi dengan pihak pemerintah desa Kaliploso dilakukan setelah survey, yaitu seminggu sebelum pelaksanaan kegiatan guna menyampaikan maksud, tujuan, sasaran, waktu, dan bentuk kegiatan. Koordinasi dilakukan antara Tim pengabdian Institut Teknologi dan Bisnis Muhammadiyah Banyuwangi dengan kepala desa Kaliploso dan beberapa jajarannya.

Setelah pemerintah desa Kaliploso menyetujui kegiatan, Tim pengabdian melakukan tahap persiapan, diantaranya mengumpulkan materi yang akan disajikan saat 
penyuluhan, menyiapkan sarana-prasarana, dan segala keperluan di saat pelaksanaan.

Kegiatan pengabdian kepada masyarakat ini dilaksanakan di balai desa Kaliploso dengan peserta sejumlah 30 orang. Peserta terdiri dari ibu-ibu PKK (Pemberdayaan kesejahteraan Keluarga) desa setempat. Pemilihan ibu-ibu sebagai sasaran peserta dikarenakan ia berperan pada banyak hal dalam suatu aktivitas rumah tangga. Adapun sebaran pekerjaan peserta disajikan pada Tabel 1 sebagai berikut.

Tabel 1. Pekerjaan peserta

\begin{tabular}{cc}
\hline Pekerjaan & Jumlah \\
\hline Ibu Rumah Tangga & 18 \\
\hline Petani & 9 \\
\hline Guru & 2 \\
\hline Wiraswasta & 1 \\
\hline Kegiatan dibuka secara formal oleh
\end{tabular}

salah satu anggota tim pengabdian dan dilanjutkan dengan penyampaian materi oleh pemateri. Sebelum pemaparan materi pengelolaan sampah, fasilitator menstimulus peserta dengan menampilkan pertanyaan terkait dengan pengelolaan limbah rumah tangga dan peserta menjawab dengan antusias sesuai pengetahuan awal mereka. Jawaban peserta beragam dengan presentase benar $36,66 \%$ dan menjawab salah sebanyak $63,33 \%$. Selanjutnya penyajian materi tentang pengelolaan limbah rumah tangga sebagaimana disajikan pada Gambar 1.

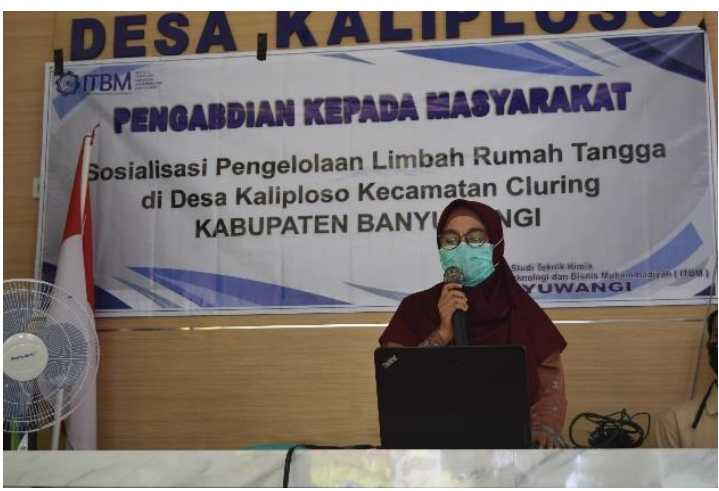

Gambar 1. Penyajian materi pengelolaan limbah rumah tangga

Pertanyaan terkait pengelolaan limbah rumah tangga yang telah dilakukan peserta selama ini, maka dengan serempak peserta menjawab bahwa limbah rumah tangga yang dihasikan hanya dibuang begitu saja di lahan kosong disekitar rumah mereka. Hal ini memperkuat salah satu alasan pengabdian masyarakat oleh Program Studi Teknik Kimia, Institut Teknologi dan Bisnis Muhammadiyah Banyuwangi. Hal ini pula mendukung ketetapan Perda Kabupaten Banyuwangi No.9 Tahun 2013 yang menyatakan bahwa pengelolaan limbah bertujuan untuk meningkatkan kesehatan masyarakat dan kualitas lingkungan serta menjadikan limbah sebagai sumber daya. Pemberdayaan masyarakat merupakan tindakan strategis berkelanjutan dalam rangka pembangunan manusia dan solusi alternatif untuk mengatasi permasalahan sampah secara mandiri (Sulistiyani dan Wulandari, 2017).

Setelah pemaparan materi, dilakukan proses diskusi dengan melakukan tanya jawab dengan peserta. Sekaligus peserta menyampaikan ide-ide tentang pengelolaan limbah rumah tangga. Sebagaimana disajikan pada Gambar 2 dan Gambar 3.

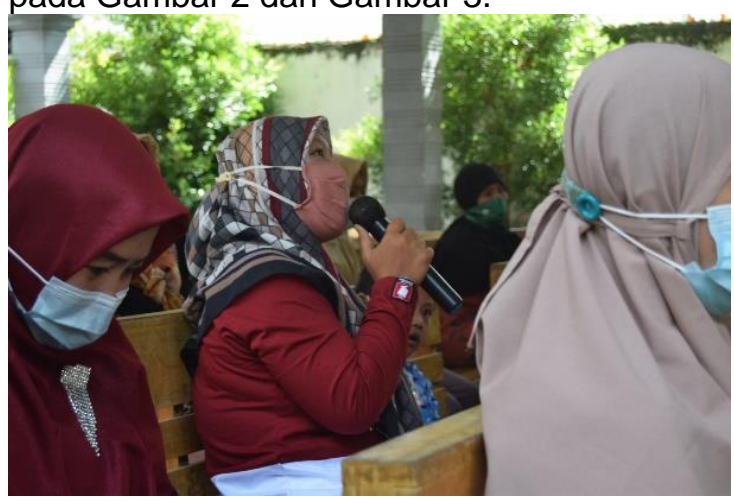

Gambar 2. Partisipasi peserta dalam proses diskusi

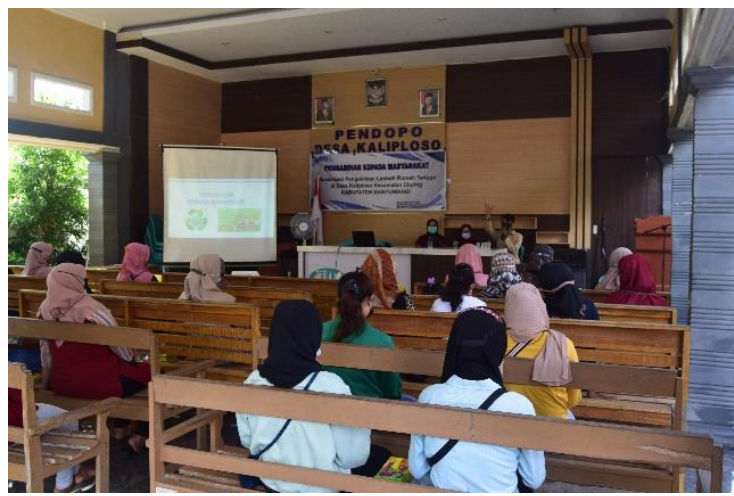

Gambar 3. Situasi proses diskusi antar pemateri dan peserta

Proses diskusi dengan peserta menghasilkan ide baru yang digunakan sebagai langkah awal gerakan mengurangi limbah rumah tangga yaitu sejumlah 13 keluarga $(43,33 \%)$ bersedia menyiapkan satu karung yang digunakan sebagai tempat sampah khusus limbah anorganik di rumah masing-masing. Sampah anorganik yang terkumpul akan dijual secara mandiri dan hasilnya dapat digunakan untuk kebutuhan sehari-hari. Tiga belas relawan yang bersedia melakukan pemilahan diharapkan pula dapat menularkan kebiasaan kecil tersebut pada tetangga sebelah tempat tinggalnya.

Setelah proses diskusi selesai, tahapan pelaksanaan selanjutnya adalah evaluasi. Evaluasi kegiatan dilakukan dengan 
menanya kepada peserta terkait materi tentang pengelolaan limbah rumah tangga yang telah diberikan dan peserta dapat menjawab benar dengan presentase $100 \%$.

\section{SIMPULAN DAN SARAN}

Pelaksanaan pengabdian kepada masyarakat yang berupa penyuluhan kepada warga desa Kaliploso terkait pengelolaan limbah rumah tangga terlaksana dengan baik. Tingkat pemahaman masyarakat mengenai pengelolaan limbah rumah tangga setelah kegiatan sebesar 100\% (30 peserta). Sesi diskusi memunculkan ide untuk melakukan pemilahan sampah anorganik menggunakan karung sebagai wadahnya yang dilakukan oleh 13 relawan $(43,33 \%)$ sebagai sampel dari masyarakat desa Kaliploso. Hal ini merupakan bukti tumbuhnya kesadaran masyarakat untuk menjaga kelestarian lingkungan.

Saran untuk pelaksanaan mewujudkan hasil diskusi adalah perlunya melakukan pendampingan dan survey secara informal di kemudian hari, dengan harapan masyarakat yang melakukan pengelolaan limbah rumah tangga secara mandiri dapat melaksanakan dengan optimal dan jumlah masyarakat yang melakukan dapat bertambah dua kali lipat dari sampel awal dan seterusnya.

\section{UCAPAN TERIMAKASIH}

Kegiatan ini terlaksana dengan baik atas dukungan banyak pihak. Tim penulis mengucapkan terima kasih kepada instansi dan pemerintah desa serta warga desa Kaliploso yang turut serta menyukseskan kegiatan ini dengan baik.

\section{DAFTAR RUJUKAN}

Nugroho, Panji. (2013). Panduan Membuat Kompos Cair. Jakarta: Pustaka Baru Press Hikmat, Harry. 2013. Strategi Pemberdayaan Masyarakat: cetakan keenam. Bandung: Humaniora.

Peraturan Daerah Kabupaten Banyuwangi Nomor 9 Tahun 2013 tentang Pengelolaan Sampah Rumah Tangga dan Sampah Sejenis Sampah Rumah Tangga

Sejati, Kuncoro. (2009). Pengolahan Sampah Terpadu. Yogyakarta: Kanisius

Sulistiyani, A.T., \& Wulandari, Y. (2017). Proses Pemberdayaan Masyarakat Desa Sitimulyo, Kecamatan Piyungan, Kabupaten Bantul dalam Pembentukan Kelompok Pengelola Sampah Mandiri. Indonesian Journal of Community Engagement. 2(2). 146-162. https://doi.org/10.22146/jpkm.27024
Suwerda, Bambang. 2012. Bank Sampah. Yogyakarta: Pustaka Rihama.

Undang-Undang Nomor 18 Tahun 2008 Tentang Pengelolaan Sampah. 